Full-field moisture induced deformation in Norway spruce: intra-ring variation of transverse swelling

\author{
Journal Article \\ Author(s): \\ Lanvermann, Christian; Wittel, Falk K.; Niemz, Peter \\ Publication date: \\ 2014-01 \\ Permanent link: \\ https://doi.org/10.3929/ethz-b-000078089
}

Rights / license:

In Copyright - Non-Commercial Use Permitted

Originally published in:

European Journal of Wood and Wood Products 72(1), https://doi.org/10.1007/s00107-013-0746-8 


\title{
Full-field moisture induced deformation in Norway spruce: intra-ring variation of transverse swelling
}

\author{
Christian Lanvermann • Falk K. Wittel • \\ Peter Niemz
}

Received: 28 March 2013/Published online: 1 October 2013

(c) Springer-Verlag Berlin Heidelberg 2013

\begin{abstract}
The transverse hygro-expansion of Norway spruce wood is studied on the growth ring level using digital image correlation. This non-destructive technique offers the possibility for a contactless study of deformation fields of relatively large areas. The measured full-field strains are segmented into individual growth rings. Whereas radial strains closely follow the density progression with the maximum in the dense latewood (LW), tangential and shear strain remain constant except for positions around the edges of the sample. A simple FE three phase growth ring model is in good agreement with the experimental values. The selective activation of individual phases like earlywood (EW), transition wood and LW demonstrates that the radial hygro-expansion is dominated by the EW deformation, whereas tangential deformation is a complex interplay of expansion and compression that needs all tissues to fully develop.
\end{abstract}

\section{Feuchteabhängige Verformung von Fichtenholz: Variabilität der Quellung quer zur Faser innerhalb von Jahrringen}

Zusammenfassung Die Quellung von Fichtenholz quer zur Faser wurde mit Hilfe digitaler Bildkorrelation auf der Jahrringebene untersucht. Mit Hilfe dieser Methode können die Deformationsfelder relativ großer Flächen zerstörungsfrei und kontaktlos ermittelt werden. Nachfolgend wurden die vollflächigen Deformationsfelder in einzelne

C. Lanvermann $(\bowtie) \cdot$ F. K. Wittel · P. Niemz

ETH Zurich, Institute for Building Materials, Schafmattstrasse 6, 8093 Zurich, Switzerland

e-mail: lanvermannchr@ethz.ch
Jahrringe segmentiert. Während die radiale Dehnung sehr stark mit dem Dichteverlauf innerhalb des Jahrringes korreliert, wobei das Dehnungsmaximum im dichten Spätholz liegt, sind die tangentiale und die Schubdehnung innerhalb des Jahrrings konstant. Die experimentellen Daten sind in guter Übereinstimmung mit denen eines einfachen dreiphasigen FE-Modells. Die selektive Aktivierung der einzelnen Phasen Frühholz, Übergangsholz und Spätholz zeigt, dass die radiale Quellung im Wesentlichen von Frühholz dominiert wird, während sich die tangentiale Quellung erst durch ein komplexes Zusammenspiel von Ausdehnung und Kontraktion zu ihrer vollen Größe entfaltet.

\section{Introduction}

Hygro-expansion of Norway spruce [Picea abies (L.) Karst.] has been studied for a long time. The well-known anisotropy with respect to the principal directions of wood [radial (R), tangential (T) and longitudinal (L)] is also well established for both hygro-expansion (e.g. Kollmann and Côté 1968) and mechanical properties (Keunecke et al. 2008; Modén and Berglund 2008a, b). The wood substance strives for equilibrium with the ambient relative humidity $(\mathrm{RH})$, while its porous structure significantly increases sorption velocity. Changes in the ambient $\mathrm{RH}$ lead to changes in the amount of water within wood, referred to as moisture content (MC). It denotes the ratio of mass of moisture over dry mass of wood. Mainly two states can be distinguished: free water (liquid or vapor) in the cell lumen and bound water within the cell wall substance (Zelinka et al. 2012). The bound water in the cell wall forms hydrogen bonds to the more or less hydrophilic wood components cellulose, hemicelluloses and lignin and 
drives the components apart (Simpson 1980). This, in turn, leads to dimensional changes by increase in the cell wall thickness, whereas almost no in-plane swelling is observed (Ishimaru and Iida 2001). The swelling anisotropy with respect to the principal wood directions clearly originates from this behavior (Boutelje 1962; Skaar 1988). Several underlying mechanisms have been proposed to explain this anisotropy, including microfibril angle (MFA), cell arrangement, ray tissue and the alternation of earlywood (EW) and latewood (LW) bands (Frey-Wyssling 1940, 1943; Boutelje 1962; Futo 1984; Bodig and Jane 1993; Lichtenegger et al. 1999; Gindl et al. 2004; Rafsanjani et al. 2012a). Due to the effect of surrounding tissue in larger specimens or structural members, compressive and tension stresses arise (Toratti and Svensson 2000; Jönsson and Svensson 2004; Gereke et al. 2009).

On a growth ring scale, several studies show considerably different behavior for EW and LW. The properties of the cells in softwoods, mainly their wall thicknesses, differ significantly from thin walled EW cells with large lumen, developed in the beginning of the vegetation period over transition wood (TW) to thick walled LW cells with small lumen formed towards the end of the vegetation period (e.g., Lanvermann et al. 2013). Hence, physical properties (Young's Modulus of elasticity, density, strength) of EW considerably differ from those of TW and LW (Kretschmann and Cramer 2007; Eder et al. 2009). In the past, several investigations revealed the different hygro-expansion of EW and LW using several techniques, showing a strong anisotropy for EW, while the LW showed a fairly isotropic behavior. A common method thereby was to analyze the swelling and shrinkage of isolated EW and LW samples or thin sections (Boutelje 1962; Futo 1984; Futo and Bosshard 1986; Perré and Huber 2007; Derome et al. 2011; Rafsanjani et al. 2012b).

The aim of the present work is to study perpendicularto-grain moisture-induced deformations on a growth ring level. For this, a commercial digital image correlation solution is applied to generate full-field deformation fields. In a next step the datasets are further processed to segment the individual growth rings as well as to transform the deformations into the orthotropic radialtangential coordinates in order to study the intra-growth ring deformations. The interpretation of the hygric behavior in terms of stress and strain fields remains incomplete, in particular the respective roles of earlyand latewood on the overall behavior, since a direct measurement of stress fields is impossible. This information is obtained from accompanying finite element (FE) calculations.

\section{Materials and methods}

\subsection{Test procedure and image acquisition}

From a board of an approximately 107-year-old Norway spruce stem, a number of 10 samples with $40 \times 40 \times 5 \mathrm{~mm}^{3}(\mathrm{R} \times \mathrm{T} \times \mathrm{L})$ were cut at positions distributed over the whole cross-section. The samples have the growth rings aligned perpendicular to one of the sample's edges. A random black and white pattern was then applied on the sample's cross-section with an airbrush gun (nozzle size $0.2 \mathrm{~mm}$ ) which is a prerequisite for digital image correlation. The samples were dried at $80^{\circ} \mathrm{C}$ and then equilibrated at increasing relative humidity steps $(\mathrm{RH})$ (20, 4565 and $95 \%)$. When they reached equilibrium, an image was taken for the subsequent evaluation of the strain fields. Therefore, the optical axis of the used camera (Allied Vision Technologies, Germany), equipped with a CCD sensor with a maximum resolution of 2,048 $\times 2,048$ pixel (resulting pixel size $23.5 \mu \mathrm{m}$ ), was aligned perpendicular to the radial-tangential surface. For each moisture increment the weight of the sample was recorded with a scale (precision $0.0001 \mathrm{~g}$, Mettler Toledo, Switzerland).

In order to record ambient conditions throughout the experiments, a data logger (DATAQ Instruments Inc., USA) was placed next to the samples. While for the low $\mathrm{RH}$ of $20 \%$ the samples were stored over a saturated salt solution [lithium chloride $(\mathrm{LiCl})]$, for the higher relative humidities a climate chamber (Feutron, Germany) was used. After completion of the conditioning at $95 \% \mathrm{RH}$, the samples were dried at $103{ }^{\circ} \mathrm{C}$, an image was taken, i.e. the reference image, and the dry masses were recorded.

\subsection{Test evaluation procedure}

The resulting images were passed to the DIC software (VIC 2D 2009, Correlated Solutions Inc., USA) which is able to track the deformation of small rectangular neighborhoods based on the principle of allocating similar gray value distributions. Herein, the oven dry image was used as the reference state. Two crucial parameters of the correlation algorithm are the subset and step parameters. The subset parameter gives the size of the rectangular neighborhood in which the cross-correlation is performed. The step parameter defines the number of pixels the center of gravity of the rectangular subset is moved until the next correlation is performed. This process is repeated until the whole area of interest (AOI) is evaluated. In this study, the most accurate results are found for a subset parameter of 9 and a step parameter of 1 . After the correlation, the displacement matrices were exported. 


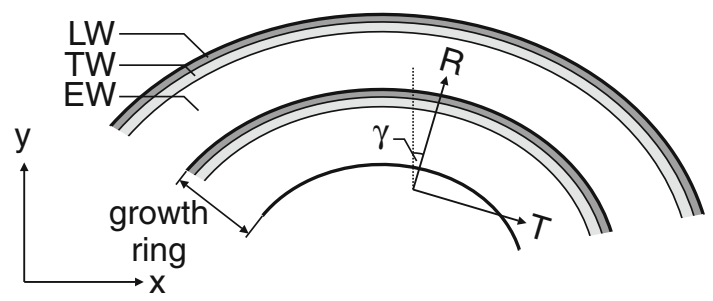

Fig. 1 Schematic growth ring

Abb. 1 Schematischer Jahrringaufbau

The further evaluation of the curved growth rings comprised the segmentation into individual rings, the interpolation of the growth rings into vectors of equal length (100 points) in the radial direction and, the averaging in the tangential direction. In order to segment the growth rings, orthographic images of the backside of the samples were acquired and the growth ring borders as well as the sample edges were drawn manually. These markings were exported as binary images that were skeletonized and transformed onto the oven dry gray scale image using the inbuilt registration tool in MATLAB ${ }^{\circledR}$, what is basically an affine transformation with at least four reference points. With the obtained transformation function, the positions of the growth ring borders were extracted from the deformation matrix and assigned to a specific growth ring. In a next step, the vertical $\left(\varepsilon_{Y Y}\right)$, horizontal $\left(\varepsilon_{X X}\right)$ and shear strains $\left(\varepsilon_{X Y}\right)$, were calculated in the $\mathrm{x} / \mathrm{y}$-image coordinate system. To transform from the $\mathrm{x} / \mathrm{y}$-system to the R/T-system, the growth ring borders are approximated with spline curves. The local slope of the approximated functions is used to calculate a vector normal to the curve which corresponds to the true radial direction of the specimen. The angle $\gamma$ between the $\mathrm{x}$ and $\mathrm{R}$ axis is $d x / d y$ (see Fig. 1). The coordinate transformation then follows the following equations (local indices dropped for simplicity):

$\varepsilon_{R}=\varepsilon_{X X} \sin (\gamma)^{2}+\varepsilon_{Y Y} \cos (\gamma)^{2}+\varepsilon_{X Y} \sin (2 \gamma)$

$\varepsilon_{T}=\varepsilon_{X X} \cos (\gamma)^{2}+\varepsilon_{Y Y} \sin (\gamma)^{2}+\varepsilon_{X Y} \sin (2 \gamma)$

$\varepsilon_{R T}=-\frac{1}{2} \sin (2 \gamma)\left(\varepsilon_{X X}-\varepsilon_{Y Y}\right)+\varepsilon_{X Y} \cos (2 \gamma)$

\subsection{Three phase growth ring model}

To calculate the internal residual stress distribution, a FE simulation of a block consisting of four $3 \mathrm{~mm}$ wide growth rings that are composed of three different zones with properties for early- (EW $0.3 \mathrm{~mm}$ ), transition- (TW $0.7 \mathrm{~mm}$ ), and latewood (LW $2 \mathrm{~mm}$ ) was used. The equivalent elastic parameters and hygro-expansion coefficients from the three regions are taken from the work by Persson (2000) and summarized in Table 1. Note that all parameter sets fulfill consistency conditions for orthotropic materials. These properties originate from a multi-scale
Table 1 Equivalent elastic parameters and hygro-expansion coefficients for earlywood, latewood and transitionwood taken from (Persson 2000)

Tab. 1 Äquivalente elastische Parameter und Quellungskoeffizienten für Früh-, Übergangs- und Spätholz (aus Perrson 2000)

\begin{tabular}{llll}
\hline Parameter & Earlywood & Transition wood & Latewood \\
\hline $\mathrm{E}_{\mathrm{L}}[\mathrm{MPa}]$ & 7710 & 11,400 & 36,400 \\
$\mathrm{E}_{\mathrm{R}}[\mathrm{MPa}]$ & 671 & 953 & 1,570 \\
$\mathrm{E}_{\mathrm{T}}[\mathrm{MPa}]$ & 82.9 & 441 & 2,100 \\
$\mathrm{G}_{\mathrm{LR}}[\mathrm{MPa}]$ & 675 & 780 & 1,760 \\
$\mathrm{G}_{\mathrm{LT}}[\mathrm{MPa}]$ & 397 & 861 & 1,770 \\
$\mathrm{G}_{\mathrm{RT}}[\mathrm{MPa}]$ & 9.23 & 10 & 43.1 \\
$v_{\mathrm{LR}}$ & 0.652 & 0.108 & 0.427 \\
$v_{\mathrm{LT}}$ & 0.552 & 1.399 & 0.546 \\
$v_{\mathrm{RT}}$ & 1.004 & 0.521 & 0.164 \\
$\alpha_{\mathrm{L}}[\% / \%]$ & 0.00047 & 0.00282 & 0.00503 \\
$\alpha_{\mathrm{R}}[\% / \%]$ & 0.23 & 0.235 & 0.335 \\
$\alpha_{\mathrm{T}}[\% / \%]$ & 0.365 & 0.386 & 0.394 \\
\hline
\end{tabular}

model and were calculated on representative cellular micro-structures of Norway spruce. A Cartesian material coordinate system is used, ignoring growth ring curvatures for simplicity. A linear thermo-elastic calculation is performed, using the analogy between moisture and temperature transport and expansion with the ABAQUS FE software. Hence, the moisture dependence of all elastic parameters and expansion coefficients, as well as all sources of material non-linearity from plastic and viscoelastic/plastic dissipation of all sorts is neglected. The FE model is shown in Fig. 8 using thermo-mechanical 20-node elements with quadratic displacement, linear temperature interpolation and reduced numerical integration (C3D20RT). Symmetry in the LR and RT plane is chosen leading to block dimensions of L-R-T of $80 \times 12 \times 120 \mathrm{~mm}$. All other four surfaces can displace freely. The temperature, respective moisture, is increased homogeneously for $\triangle M C=14.2 \%$. Three cases are calculated: (a) swelling of all phases (b) swelling LW and nonswelling EW/TW, and (c) EW/TW and non-swelling LW.

\section{Results and discussion}

In the current study the hygro-expansion of wood was studied on a growth ring level on the transverse surface of wood. The full-field orthotropic strains were segmented into individual growth rings and averaged along the tangential direction (i.e. the same growth ring position). As a first step the relation between the detected strains and the distance to the sample edge is analyzed. Furthermore, the relation of the strains on a growth ring level is investigated as well as their relation with increasing MC. As a last step 
the moisture-dependent degree of anisotropy is discussed. Finally, the results of the FE simulations regarding the role of the different zones towards the anisotropic hygroexpansion of bulk wood are discussed.
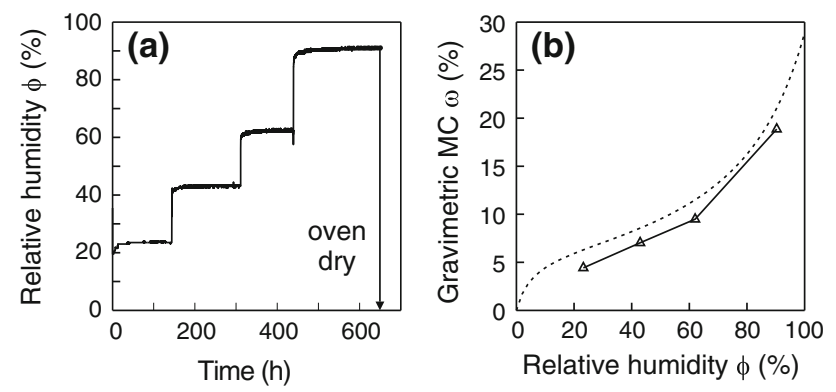

Fig. 2 Recorded RH steps (a) and corresponding MC levels (b) in comparison to computed mean sorption isotherm according to the Hailwood-Horrobin model (taken from Popper and Niemz (2009))

Abb. 2 a Gemessene relative Luftfeuchtigkeitsschritte und b zugehörige Holzfeuchte im Vergleich zur berechneten mittleren Sorptionsisotherme nach Hailwood-Horrobin (nach Popper und Niemz (2009)

\subsection{Sorptive behavior}

The RH readings of the data logger placed adjacent to the samples throughout the experiments are shown in Fig. 2a and range from 23 up to $90 \% \mathrm{RH}$. The resulting sorption isotherm as the mean of all samples in comparison to the computed mean sorption isotherm according to the Hailwood-Horrobin model [taken from Popper and Niemz 2009)] is given in Fig. $2 b$. The comparison between the model prediction and actual MCs leads to a good agreement, since the model represents the mean sorption isotherm and the samples were conditioned in adsorption. According to Pang and Herritsch (2005); Moon et al. (2010) and Dvinskikh et al. (2011), the presented mean MC levels are homogeneous for the entire sample since gravimetric MC is of global nature.

\subsection{Full-field strain distribution}

The full-field strain distributions of the evaluated AOI are given in Fig. 3 for one sample. The $\varepsilon_{Y Y}$ strain field (Fig. 3c) shows pronounced differences that correspond to the growth rings, with the maxima at the growth ring borders
Fig. 3 Sample surface with speckle pattern (a), evaluated area of interest (AOI) (dashed line) identified growth ring boundaries (solid lines) and corresponding surface strains (b-d) at an MC of $19.2 \%$ at a RH of $90 \%$

Abb. 3 Probenoberfläche mit Specklemuster (a), ausgewertete Region (gestrichelte Linie) Jahrringgrenzen (durchgezogene Linie) und zugehörige

Oberflächendehnungen

(b-d) bei einer Holzfeuchte von

$19,2 \%$ und einer

Luftfeuchtigkeit von $90 \%$
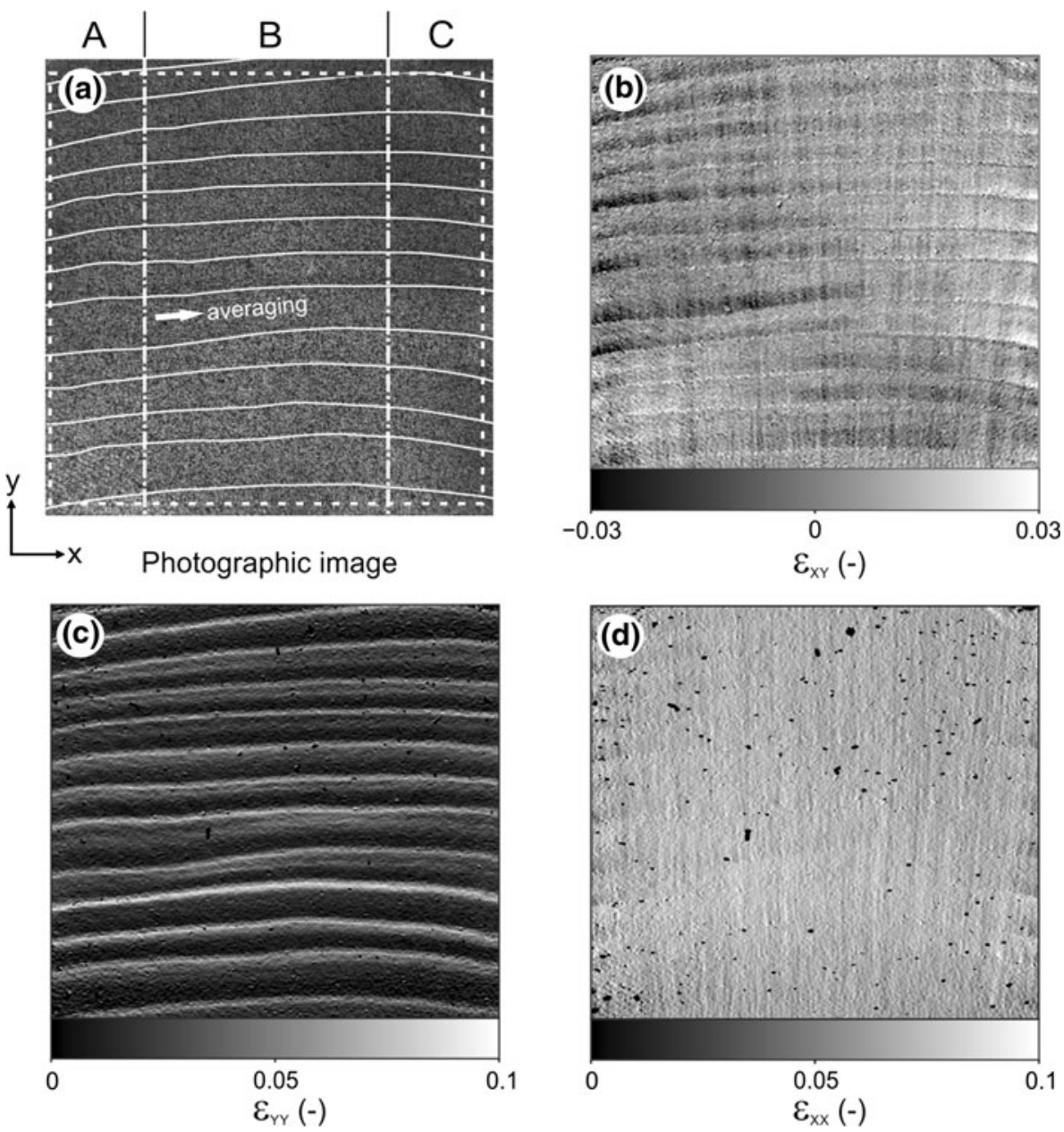
and minima in between. In the $\varepsilon_{X X}$ strain field (Fig. 3d), no such pattern can be found, instead the strain is fairly constant within a range of $1-2 \%$, only a slight tendency towards slightly higher values in the lower center portion can be seen. The shear strain $\varepsilon_{X Y}$ (Fig. 3b) shows a slight correlation with the growth ring structure with elevated values at the growth ring borders and lower values in between. A slight concentration of higher strains can be seen in the lower left and center right position of the AOI.

However, the nature of these full-field representations is rather qualitative than quantitative. Therefore, the datasets were segmented along the growth ring borders, interpolated to 100 points in radial direction and averaged along the tangential direction, i.e. only averaging points in the same growth ring position.

\subsection{Identification of boundary effects}

In order to study the effect of boundary conditions, the growth ring wise strains are further segmented according to the regions A, B, and C (c.f. Fig. 3a) and shown in Fig. 4. The first and last columns show the mean strains of regions $A$ and $\mathrm{C}$ that correspond to approximately 3 growth ring widths (mean growth ring width: $2.6 \mathrm{~mm}$ ) and represent the boundary affected regions. The remaining center (region B Fig. 3a) data is shown in the center column. The oscillatory behavior of the radial strain with maxima of about 5-7 \% and minima of around $1 \%$ as seen in the full-field data is clearly reflected in the segmented data. A clear influence of the position on the AOI cannot be found for $\varepsilon_{R}$. The tangential strain is constant at around $6 \%$ strain in the center of the AOI, whereas the outer regions show a slight wave-like trend with a variation of about $1 \%$ where the maxima correspond to the maxima in the radial strain. A similar behavior can be found for the shear strain. Whereas the outer regions show a much higher variation (about $2 \%$ ) with reversed sign for the opposite sides which is a direct consequence of free boundaries, the center shows a variation around zero with much lower amplitude (around 1\%) which basically can be regarded as zero.
Fig. 4 Influence of sample position on detected radial, tangential, and shear strains at $19.2 \%$ MC. The first and last columns represent the boundary-affected regions (approximately 3 growth ring widths)

Abb. 4 Einfluss der Position auf der Probe auf radiale, tangentiale und Schubdehnung bei einer Holzfeuchte von $19,2 \%$. Die erste und letzte Spalte entsprechen den durch Randeffekte beeinflussten Bereichen (etwa 3 Jahrringbreiten)
A
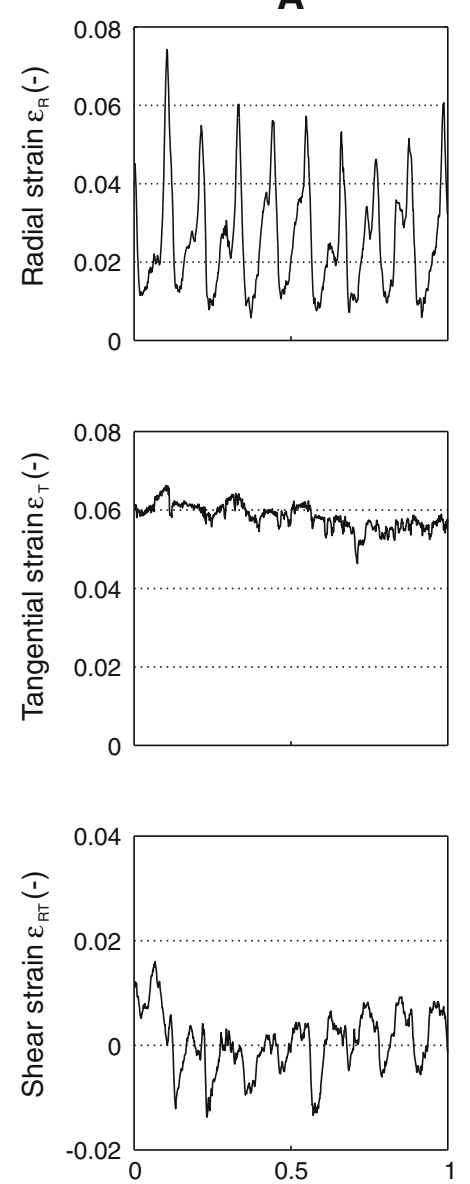

B
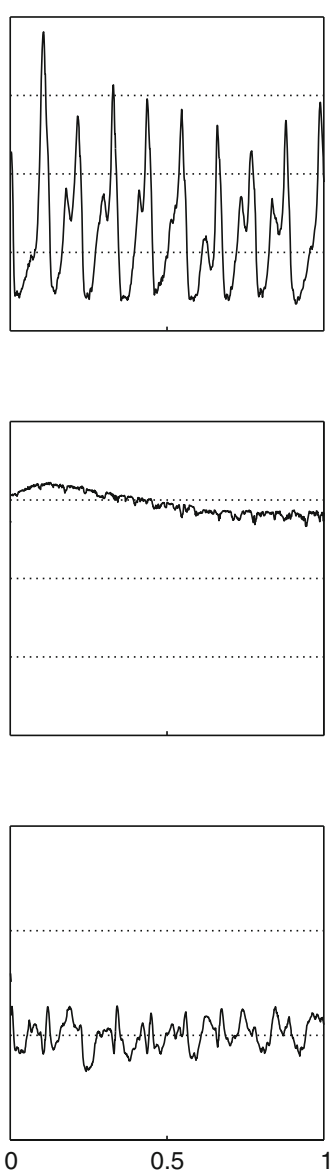

Relative radial sample position (-)
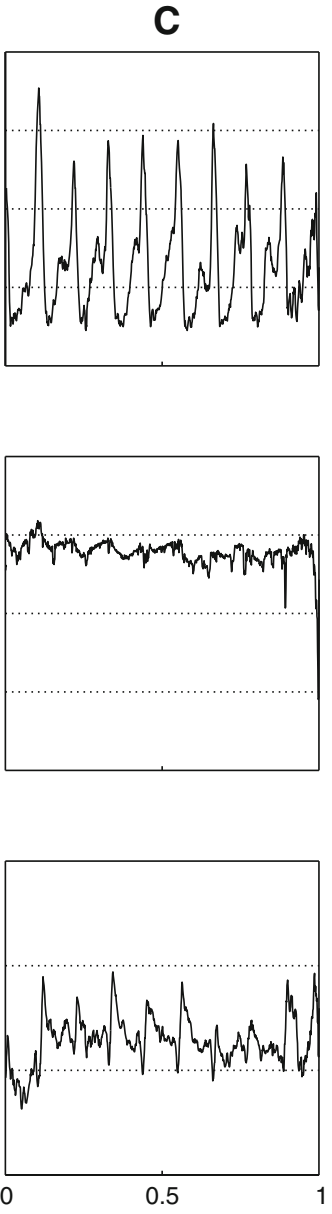

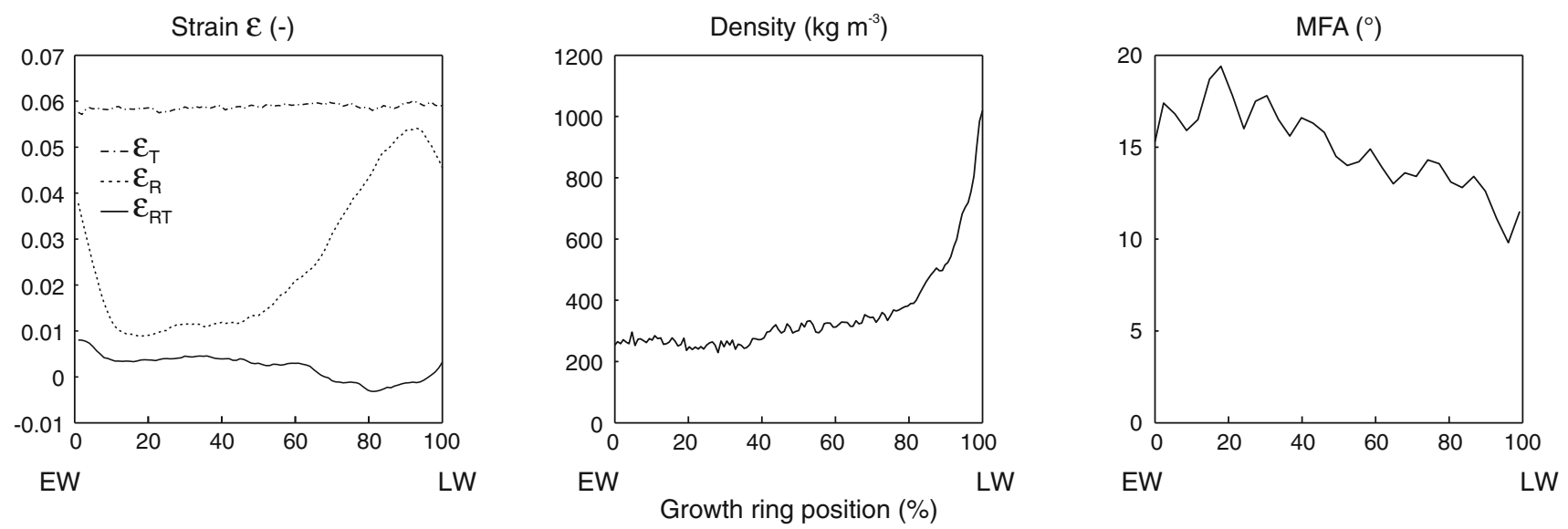

Fig. 5 Radial, tangential, and shear strain development for an individual growth ring at $19.0 \% \mathrm{MC}$ at the center region and the corresponding density and MFA development (for detailed information see Lanvermann et al. 2013)

Abb. 5 Radiale, tangentiale und Schubdehnung für einen einzelnen Jahrring bei einer Holzfeuchte von 19,0 \% im mittleren Bereich der Probe und zugehörige Dichte- und MFA Verteilung (entnommen aus Lanvermann et al. 2013)

\subsection{Intra-ring strain distribution}

A close-up view on the hygro-expansion strains and their interrelation in one single growth ring taken from the center region of the AOI as well as the corresponding density and MFA distribution is given in Fig. 5. The density and MFA measurements were performed using X-ray densitometry and X-ray diffraction on samples adjacent to the present samples. For detailed information see Lanvermann et al. (2013). Where the tangential strain $\left(\varepsilon_{T}\right)$ can be regarded as constant as a consequence of boundary constraints, the radial strain $\left(\varepsilon_{R}\right)$ closely follows the density progression (Spearman's $\rho$ : 0.934), where the lowest strains and densities are in the EW and the highest strains and densities in LW, which is in line with former measurements (Kifetew et al. 1997; Keunecke et al. 2012). The opposite relation can be found regarding $\varepsilon_{R}$ and MFA (Spearman's $\rho$ : -0.934). The shear strain $\left(\varepsilon_{R T}\right)$ varies within $\pm 0.5 \%$ with slightly positive values in EW and negative ones in LW.

\subsection{Evolving strain distribution with increasing $\mathrm{RH}$}

The strains as the mean of all segmented growth rings $(\mathrm{n}=99)$ with increasing RH from 23 to $90 \%$ within the center of the samples are given in Fig. 6. With increasing $\mathrm{RH}$, and thus increasing MC, the $\varepsilon_{R}$ profile becomes more pronounced. This trend is clearly reflected in the radial differential swelling coefficients $\alpha_{R}$ for EW and LW as given in Table 2. With increasing $\mathrm{RH}, \varepsilon_{T}$ remains independent on the position inside the growth ring. Over all, compared to the other strains, $\varepsilon_{R T}$ is one order of magnitude smaller. Apart from the highest RH step, where a variation from -0.1 to $+0.1 \%$ was found, no clear trend can be seen with increasing RH and be regarded as within the measurement uncertainty. Furthermore, regions close to the growth ring borders are prone to artifacts since the employed cross-correlation method inevitably causes a certain smoothing that can be minimized but never completely omitted.

\subsection{Swelling anisotropy}

The anisotropic swelling (and mechanical) behavior of bulk wood is also represented on a growth ring level. The swelling ratio $\varepsilon_{T} / \varepsilon_{R}$ for the observed RH steps along a single growth ring is given in Fig. 7 and shows an impressive data collapse for the different RH levels. Here, in line with other investigations (Derome et al. 2011; Rafsanjani et al. 2012b), EW shows the highest degree of anisotropy (mean: 3.90) and LW is almost isotropic (mean: 1.32) with an almost linear transition within the growth ring. Due to the constancy of $\varepsilon_{T}$, the anisotropic hygric behavior is solely determined by differences in $\varepsilon_{R}$ which leads to an overall mean swelling ratio of 2.50 .

The presented method is not, however, able to resolve the underlying mechanisms that lead to the different degrees of anisotropy of EW and LW. A possible explanation regarding the different behavior of the tissues may be found in inhomogeneities in the cellular structure. But, due to the modeling approach, it is possible to evaluate the contribution of EW and LW to the mean strain, which corresponds to the swelling of bulk wood.

\subsection{FE simulation}

First, strains are measured along path 1 (see Fig. 8), that is along the intersection line of the two symmetry planes. The 

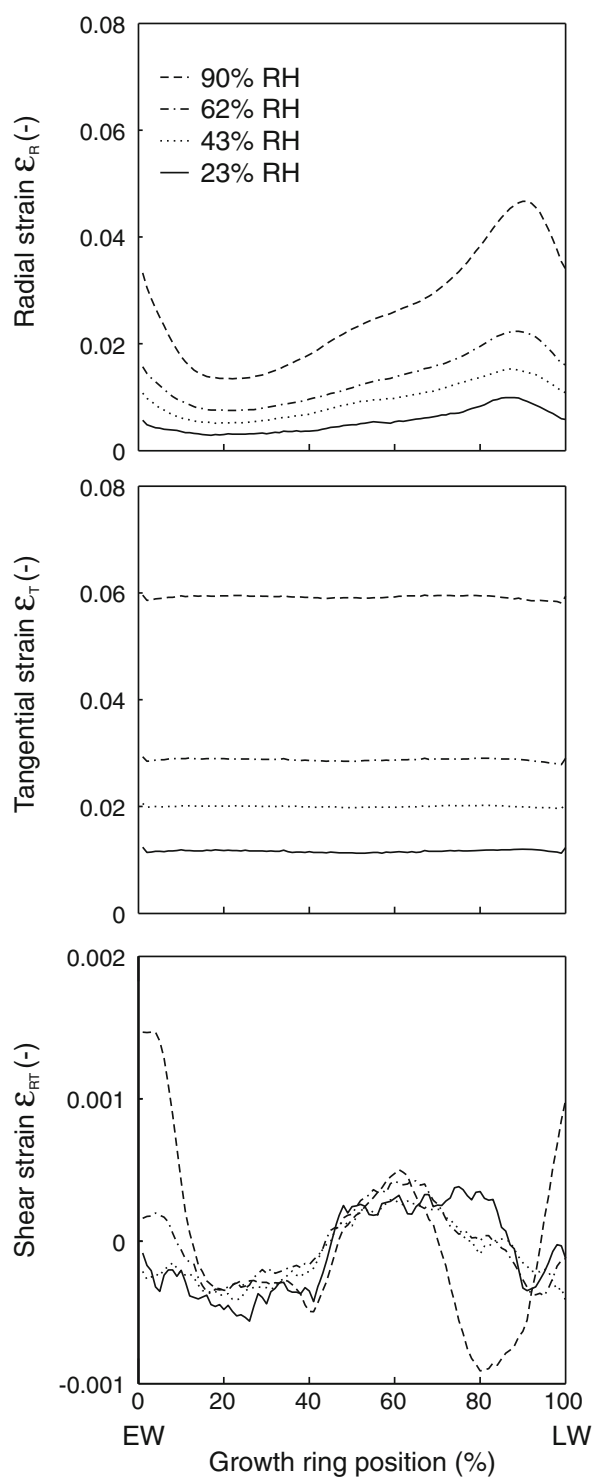

Fig. 6 Evolution of radial, tangential, and shear strains for the individual RH steps calculated as the mean of all growth rings Abb. 6 Radiale, tangentiale und Schubdehnung für die einzelnen RH Stufen berechnet als Mittelwert aller segmentierten Jahrringe results of the simulation confronted with the measurements (Fig. 9) show surprisingly good agreement considering the simple background of the FE model, although $\varepsilon_{R}$ is overestimated for EW. This overestimation clearly originates from the much higher $\alpha_{R}$ as found by Persson (2000) compared to the present work. For consistency reasons, it was decided to adopt the value of Persson. The steps in the radial strain for the different tissues EW, TW and LW support the observation of the strong correlation between measured strain and density inside a growth ring (Fig. 5). The effect of free surfaces is shown in Fig. 10. As can be seen, RT-shear stress becomes insignificant after a distance of approximately 3 growth rings which corresponds to RTshear strain (Fig. 3). The shear in the LR and LT does reach much less into the bulk. As a result, a typical wavy surface is observed (see Fig. 10).

The FE model gives the possibility not only to compute the swelling of all tissues [case (a)], but also to study the effect of isolated swelling of LW only [case (b)] or EW/TW only [case (c)]. The average radial swelling strains for the three cases measured inside the system are (a) $3.39 \%$, (b) $0.064 \%$, and (c) $3.3 \%$, while the local strains along path 1 (see Fig. 8) are given in Fig. 11. It is very interesting to note that the radial strain is basically dominated by the EW/TW. However, the radial strain consists not only of expansion, but also of lateral contraction. For case (b), due to its expansion, LW is put under tension and compresses the EW/TW region. This results in negative swelling strains for the EW/TW regions and a very low mean strain. Vice versa is important for case (c) which leads to a radial mean strain for EW/TW swelling only that is close to case (a) where all tissues contribute to the radial swelling (see Fig. 11). The tangential strain needs swelling of all growth ring regions to fully develop. Otherwise the balance of tensile and compressive stresses leads to a decreased strain. Note that the slope of the tangential strains is due to small system deflection around the longitudinal axis caused by the limited number of growth rings in this model.

Table 2 Effective swelling properties (density in $\mathrm{kg} \mathrm{m}^{-3}$, swelling coefficients $\alpha$ in $\%$ strain/\% moisture content)

Tab. 2 Effektive Quellungskoeffizienten (Dichte in $\mathrm{kg} \mathrm{m}^{-3}$, Quellungskoeffizient $\alpha$ in \% Dehnung/\% Holzfeuchteänderung)

\begin{tabular}{|c|c|c|c|c|c|c|c|c|c|c|}
\hline & \multicolumn{4}{|c|}{ Earlywood } & \multicolumn{3}{|c|}{ Latewood } & \multicolumn{3}{|c|}{ Bulk wood } \\
\hline & $\rho_{0}$ & $\alpha_{R}$ & $\alpha_{T}$ & $\alpha_{T} / \alpha_{R}$ & $\alpha_{R}$ & $\alpha_{T}$ & $\alpha_{T / \alpha_{R}}$ & $\alpha_{R}$ & $\alpha_{T}$ & $\alpha_{T} / \alpha_{R}$ \\
\hline Present work & 365 & 0.07 & 0.33 & 3.90 & 0.25 & 0.33 & 1.32 & 0.14 & 0.33 & 2.36 \\
\hline (Rafsanjani et al. 2012b) & 443 & 0.07 & 0.21 & 3.00 & 0.30 & 0.35 & 1.17 & 0.17 & 0.31 & 1.82 \\
\hline$(\text { Nakato } 1958)^{\mathrm{a}}$ & - & 0.45 & 0.45 & 1.00 & 0.50 & 0.60 & 1.20 & - & - & \\
\hline (Persson 2000) & 400 & 0.23 & 0.36 & 1.59 & 0.33 & 0.39 & 1.18 & - & - & \\
\hline (Kollmann and Côté 1968) & 375 & - & - & - & - & - & - & 0.19 & 0.37 & 1.95 \\
\hline
\end{tabular}

a Pure cell wall material 


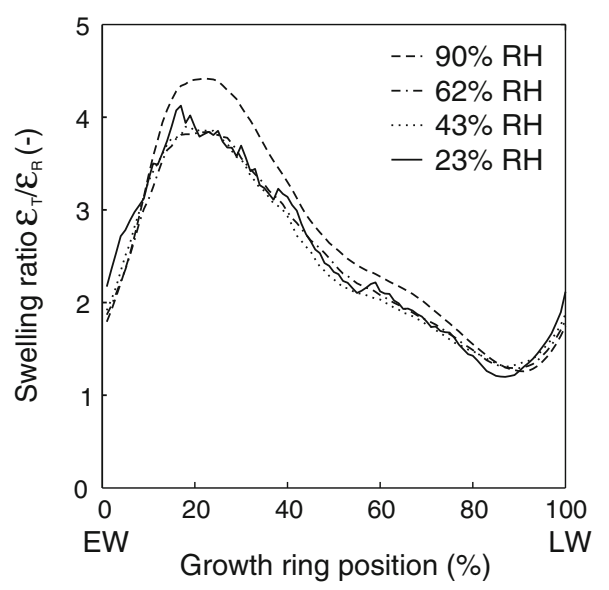

Fig. 7 Swelling ratio development within the growth rings for the individual RH steps

Abb. 7 Anisotropieverlauf innerhalb der Jahrringe für die einzelnen RH Stufen

\section{Conclusion}

In the current work, the moisture-induced swelling perpendicular-to-grain within growth rings is investigated using digital image correlation, and the contribution of EW and LW is modeled using a simple FEM simulation. The growth ring segmentation and averaging along local anatomic directions leads to a significant increase in quality of the data, results in a representative dataset due to the number of growth rings investigated.

The continuous full-field principal and the segmentation show a clear dependence of sample position on tangential and shear strain. Whereas tangential strain shows a pronounced correlation with high density regions resulting in a typical wavy surface, this phenomenon vanishes approximately 3 mean growth ring widths from the edges leading to a constant deformation. The same was found for the shear strain that basically is zero in the edge-unaffected center region. The close correlation between density and radial strain is clearly confirmed where the high density LW exhibits larger strains than the low density EW. These relations are confirmed for all investigated RH steps. The anisotropic deformation is highest in the thin-walled EW and gradually decreases to thick-walled LW that is almost isotropic.

These findings are in good agreement with the simulation of a simple FEM model consisting of the three main regions, EW, TW and LW. Furthermore, the model reveals that the anisotropic behavior of macroscopic wood is a complex interplay of the alternation of the three wood tissues.

A potential practical application of the gained insight may be found in the design of wood bondings and coatings. Therefore, changes in the MC lead to stresses at the interface not only on a global but also on microscale in EW
Fig. 8 FE model consisting of four growth rings and respective materials earlywood (EW), transition wood (TW), and latewood (LW). All dimensions in $\mathrm{mm}$. Note that the radial axis is oriented from pith to bark Abb. 8 FE Modell bestehend aus den Materialien: Frühholz (EW), Übergangsholz (TW) und Spätholz (LW). Alle Angaben in $\mathrm{mm}$. Die radiale Achse ist vom Kern zum Kambium ausgerichtet

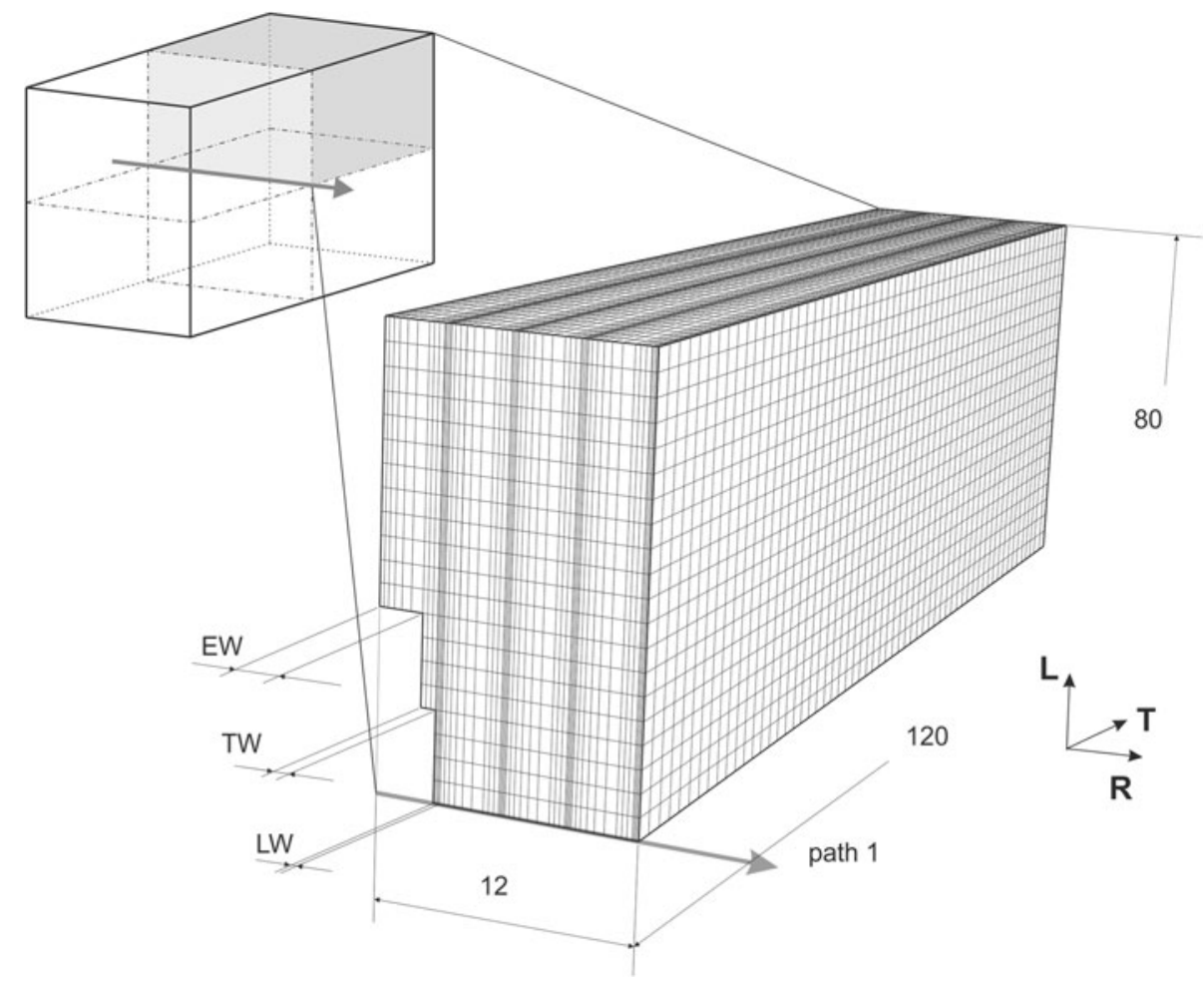




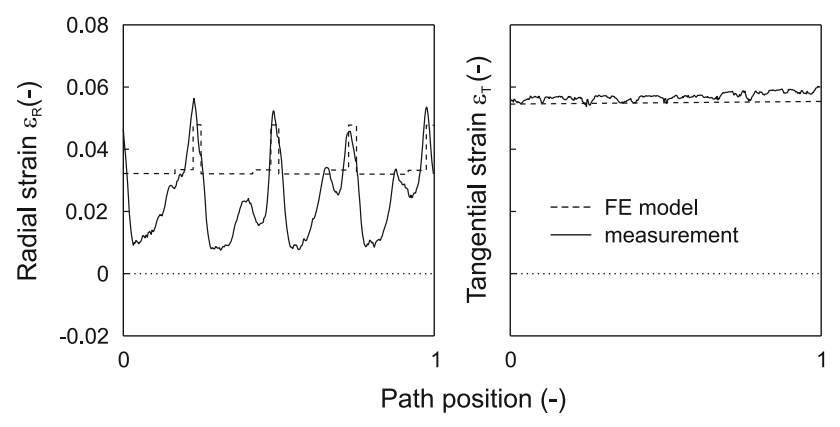

Fig. 9 FE model and measurement confrontation at $14.2 \% \mathrm{MC}$ Abb. 9 Vergleich zwischen FE Modell und Messungen bei einer Holzfeuchte von $14,2 \%$

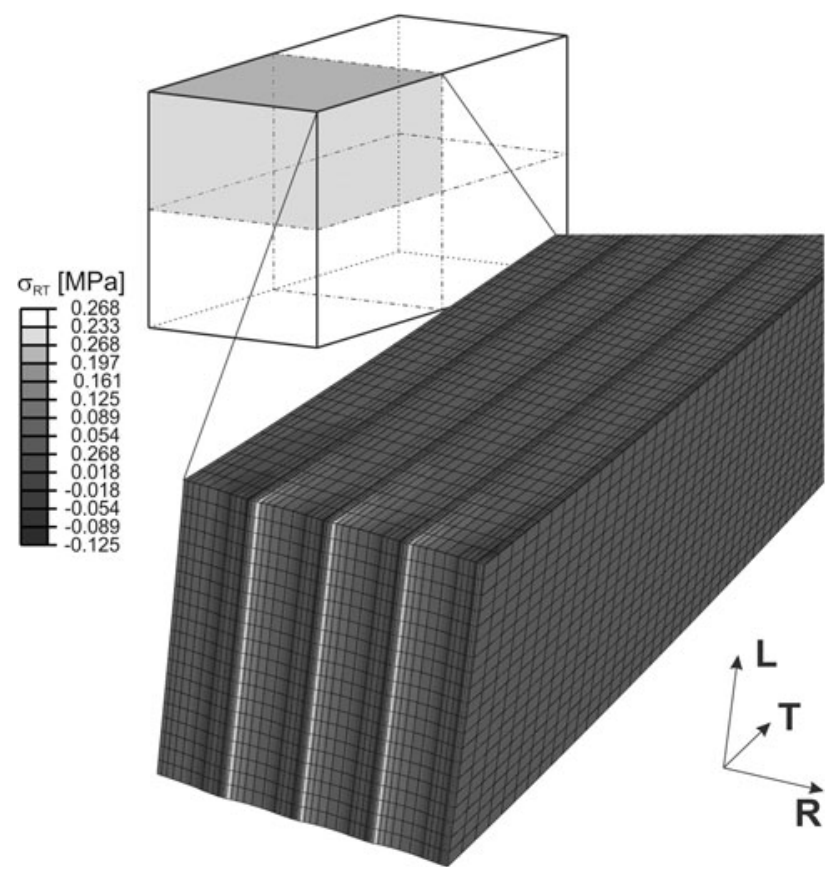

Fig. 10 Shear stress distribution at the system edges. Note that displacements are magnified by a factor of 20

Abb. 10 Schubspannungen an den Rändern des simulierten Systems. Die Verschiebungen wurden um den Faktor 20 verstärkt

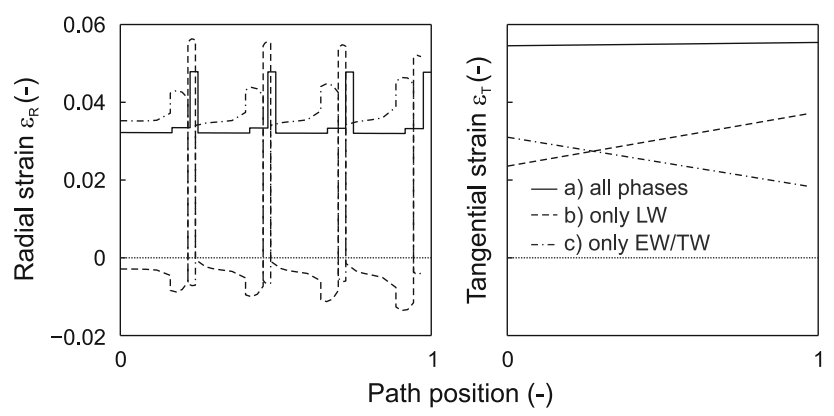

Fig. 11 Radial and tangential swelling strains along path 1 for the 3 studied cases ( $a$ all materials, $b$ LW only and $c$ LW/TW only) Abb. 11 Radiale und tangentiale Quellung entlang Pfad 1 für die 3 simulierten Fälle ( $a$ alle Materialien, $b$ nur LW, $c$ nur EW/TW) and LW. In future investigations, this concept should be extended to hardwoods and hygro-mechanical behavior on the growth ring scale.

Acknowledgments The authors are grateful for the support by the Swiss National Science Foundation (Grant No. 125184).

\section{References}

Bodig J, Jane B (1993) Mechanics of wood and wood composites. Krieger, Malabar

Boutelje JB (1962) The relationship of structure to transverse anisotropy in wood with reference to shrinkage and elasticity. Holzforschung 16(2):33-46

Derome D, Griffa M, Koebel M, Carmeliet J (2011) Hysteretic swelling of wood at cellular scale probed by phase-contrast X-ray tomography. J Struct Biol 173(1):180-190

Dvinskikh SV, Henriksson M, Berglund LA, Furó I (2011) A multinuclear magnetic resonance imaging (MRI) study of wood with adsorbed water: estimating bound water concentration and local wood density. Holzforschung 65(1):103-107

Eder M, Jungnikl K, Burgert I (2009) A close-up view of wood structure and properties across a growth ring of Norway spruce (Picea abies [L] Karst.). Trees Struct Funct 23 (1):79-84

Frey-Wyssling A (1940) Die Ursache der anisotropen Schwindung des Holzes. Eur J Wood Prod 3(11):349-353

Frey-Wyssling A (1943) Weitere Untersuchungen über die Schwindungsanisotropie des Holzes. Eur J Wood Prod 6(7):197198

Futo LP (1984) On the distribution of tension in wood tissue after drying. 2. Moisture deformation as a factor in the formation of tensions related to swelling rate. Eur J Wood Prod 42(4): 131-136

Futo LP, Bosshard HH (1986) On the shrinkage anisotropy of beech wood. Eur J Wood Prod 44(12):459-463

Gereke T, Hass P, Niemz P (2009) Moisture-induced stresses and distortions in spruce cross-laminates and composite laminates. Holzforschung 64(1):127-133

Gindl W, Gupta HS, Schoberl T, Lichtenegger HC, Fratzl P (2004) Mechanical properties of spruce wood cell walls by nanoindentation. Appl Phys A Mater Sci Process 79(8):2069-2073

Ishimaru Y, Iida I (2001) Transverse swelling behavior of Hinoki (Chamaecyparis obtusa) revealed by the replica method. J Wood Sci 47(3): 178-184

Jönsson J, Svensson S (2004) A contact free measurement method to determine internal stress states in Glulam. Holzforschung 58(2): $148-153$

Keunecke D, Hering S, Niemz P (2008) Three-dimensional elastic behaviour of common yew and Norway spruce. Wood Sci Technol 42(8):633-647

Keunecke D, Novosseletz K, Lanvermann C, Mannes D, Niemz P (2012) Combination of X-ray and digital image correlation for the analysis of moisture-induced strain in wood: opportunities and challenges. Eur J Wood Prod 70(4):407-413

Kifetew G, Lindberg H, Wiklund M (1997) Tangential and radial deformation field measurements on wood during drying. Wood Sci Technol 31(1):35-44

Kollmann FF, Côté WA (1968) Principles of Wood Science and Technology: Part I Solid Wood. Springer, Berlin

Kretschmann DE, Cramer SM (2007) The role of earlywood and latewood on dimensional stability of loblolly pine. In: Proceedings of the Compromised Wood Workshop, Christchurch, NZ, 
January 29-30 2007. Wood Technology Research Centre, School of Forestry, University of Canterbury

Lanvermann C, Schmitt U, Evans R, Hering S, Niemz P (2013) Distribution of structure and lignin within growth rings of Norway spruce. Wood Sci Technol

Lichtenegger H, Reiterer A, Stanzl-Tschegg S, Fratzl P (1999) Variation of cellulose microfibril angles in softwoods and hardwoods: a possible strategy of mechanical optimization. J Struct Biol 128:257-269

Modén CS, Berglund LA (2008a) Elastic deformation mechanisms of softwoods in radial tension: cell wall bending or stretching? Holzforschung 62(5):562-568

Modén CS, Berglund LA (2008b) A two-phase annual ring model of transverse anisotropy in softwoods. Compos Sci Technol 68(14):3020-3026

Moon RJ, Wells J, Kretschmann DE, Evans J, Wiedenhoeft AC, Frihart CR (2010) Influence of chemical treatments on moistureinduced dimensional change and elastic modulus of earlywood and latewood. Holzforschung 64(6):771-779

Nakato K (1958) On the cause of the anisotropic shrinkage and swelling of wood. IX. On the relationship between the microscopic structure and the anisotropic shrinkage in the transverse section (2). J Jpn Wood Res Soc 4(4):131-141

Pang S, Herritsch A (2005) Physical properties of earlywood and latewood of Pinus radiata D. Don: Anisotropic shrinkage, equilibrium moisture content and fibre saturation point. Holzforschung 59
Perré P, Huber F (2007) Measurement of free shrinkage at the tissue level using an optical microscope with an immersion objective: results obtained for Douglas fir (Pseudotsuga menziesii) and spruce (Picea abies). Ann For Sci 64(3):255-265

Persson K (2000) Micromechanical modelling of wood and fibre properties. Doctoral Thesis, Lund University

Popper R, Niemz P (2009) Wasserdampfsorptionsverhalten ausgewählter heimischer und überseeischer Holzarten. Bauphysik 31(2):117-121

Rafsanjani A, Derome D, Carmeliet J (2012a) The role of geometrical disorder on swelling anisotropy of cellular solids. Mech Mater 55:49-59

Rafsanjani A, Derome D, Wittel FK, Carmeliet J (2012b) Computational up-scaling of anisotropic swelling and mechanical behavior of hierarchical cellular materials. Compos Sci Technol 72(6):744-751

Simpson W (1980) Sorption theories applied to wood. Wood Fiber Sci 12(3):183-195

Skaar C (1988) Wood-water relations. Springer, Heidelberg

Toratti T, Svensson S (2000) Mechano-sorptive experiments perpendicular to grain under tensile and compressive loads. Wood Sci Technol 34(4):317-326

Zelinka SL, Lambrecht MJ, Glass SV, Wiedenhoeft AC, Yelle DJ (2012) Examination of water phase transitions in Loblolly pine and cell wall components by differential scanning calorimetry. Thermo chim Acta 533:39-45 